\title{
Danger degrees adjustment for the Monte Alegre Formula (FMA)
}

\author{
W. T. Wendling, R. V. Soares, A. C. Batista \& A. F. Tetto \\ Forest Fire Laboratory, Federal University of Paraná, Brazil
}

\begin{abstract}
The Monte Alegre Formula (FMA) is the most used fire danger index in Brazil to determine forest fire danger degree and planning prevention and suppression activities. This research aimed to adjust the danger degree levels of the FMA index in order to increase its efficiency to predict forest fires. A database consisted of thirty years of fire records and meteorological data from a forest district located in the County of Telemaco Borba, Parana State, southern Brazil was used to carry out the research. Simulations comprised 5 and 10 year periods, discriminating the occurrences in two annual seasons, a dry (May to September) and a humid (October to April), by monthly average relative humidity criterion. Trends in frequencies of fire occurrences, and season periods, were compared to the total annual period and corrected by the considered optimal values for planning the suppression structure. After that, the FMA original danger degree values were mathematically recalculated in order to obtain the lower and upper limits of the new five levels danger scale, to be used in the future. The limits of the adjusted danger degrees presented differences between the two annual seasons (dry and humid), as well as between these and the total annual period, what indicates the efficiency of the proposed methodology. The application of the new methodology could be viable also in other geographic regions.

Keywords: fire danger index, fire control, forest protection.
\end{abstract}

\section{Introduction}

The knowledge of the daily danger degree is an essential tool for decision making regarding forest fire control. For this purpose, there are the fire danger indices, which indicate the possibility of fire occurrence and/or propagation based on the weather conditions of the day or from a sequence of days [1]. 
Nunes et al. [2] state that the calculation of adequate fire indices is very important for increasing fire suppression planning and action efficiency, with favorable economic impact.

There are several fire danger indices. Some are classified as occurrence indices, like Telicyn [3], Angstron, Nesterov, and Monte Alegre Formula [1]. Others are classified as propagation indices, like Monte Alegre Formula Plus [4], Canadian Forest Fire Weather Index [5], The National Fire Danger Rating System [6], and the Icona/Italian-CFS [7].

In Brazil, Soares [8], in 1972 developed the first national forest fire danger index, named Monte Alegre Formula (FMA). According to the same author, the FMA is an accumulative index that uses two meteorological variables: the air relative humidity and the daily precipitation. The FMA has been successively used in regions that present climatic conditions similar to that ones from the region that provided the data for its development - the central region of Paraná State, southern Brazil. It can also be used in other regions with an adaptation of the danger scale. Tetto et al. [9], for instance, established new danger classes' intervals for using the FMA in Irati, Fernandes Pinheiro, Teixeira Soares, and Imbituva counties.

The objective of this research is to present a methodology for adjusting the levels of the Monte Alegre Formula danger degree with the purpose of improving the index efficiency and, therefore, leading to a more realistic fire prevention and suppression planning.

\section{Methodology}

\subsection{Study area location}

The research was developed in the Telemaco Borba County, State of Paraná, Brazil, between the coordinates $24^{\circ} 03^{\prime}$ and $24^{\circ} 28^{\prime} \mathrm{S}$ and $50^{\circ} 21^{\prime}$ and $50^{\circ} 43^{\prime} \mathrm{W}$. The area comprises the "Monte Alegre" forest district, the largest continuous forested area in Brazil, totalizing approximately 140,000 ha. The topography of the region is slightly undulated and the average altitude is $850 \mathrm{~m}$ above sea level. The mean annual precipitation is $1490 \mathrm{~mm}$, with a hydric surplus of $557 \mathrm{~mm} /$ year, well distributed over the year. The average annual temperature is $19^{\circ} \mathrm{C}$ and the mean relative humidity $76.5 \%$. According to Koppen's classification the local climate belongs to the type $\mathrm{Cfb}$, temperate, humid, without a dry season, with mild summers and periodic frosts $[4,8,10]$.

\subsection{Utilized data}

The information utilized in this research are forest fire occurrence records obtained from a data bank organized by "Klabin" Company, the biggest Brazilian pulp and paper producer The records started in 1965, after a big fire occurred in 1963 that burned most of the company's existent forest area. The meteorological data were provided by IAPAR (Agronomic Institute of Paraná) 
The main variable of the research was the daily fire danger, calculated by the Monte Alegre Formula (FMA). The index equation, developed by Soares [8] is:

$$
F M A=\sum_{i=1}^{n}\left(100 / H_{i}\right)
$$

where:

$\mathrm{FMA}=$ Monte Alegre Formula (daily Forest fire danger índex);

$\mathrm{H}=$ Relative humidity $(\%)$ at 1:00PM;

$\mathrm{N}=$ Number of $i$ days without precipitation $\geq 13.0 \mathrm{~mm}$.

As the IAPAR meteorological station only records this variable at 3:00 PM, the 1:00 PM relative humidity was estimated using the regression equation proposed by Nunes et al. [2]:

$$
\mathrm{H}_{1: 00}=2.451510 \mathrm{H}_{3: 00} \quad\left(\mathrm{R}^{2}=0.8639\right)
$$

The summation of the FMA depends upon the daily precipitation, according to the restrictions presented in Table 1 . The danger classes are presented in Table 2.

Table 1: Restrictions to the FMA summation according to the daily precipitation.

\begin{tabular}{|c|c|}
\hline $\begin{array}{c}\text { Precipitation } \\
(\mathrm{mm})\end{array}$ & Calculation modification \\
\hline$\leq 2.4$ & None \\
\hline $2.5-4.9$ & $\begin{array}{c}\text { Subtract } 30 \% \text { from the calculated FMA and } \\
\text { add }\left(100 / \mathrm{H}_{\mathrm{i}}\right) \text { of the day; }\end{array}$ \\
\hline $5.0-9.9$ & $\begin{array}{c}\text { Subtract } 60 \% \text { from the calculated FMA and } \\
\text { add }\left(100 / \mathrm{H}_{\mathrm{i}}\right) \text { of the day; }\end{array}$ \\
\hline $10.0-12.9$ & $\begin{array}{c}\text { Subtract } 80 \% \text { from the calculated FMA and } \\
\text { add }\left(100 / \mathrm{H}_{\mathrm{i}}\right) \text { of the day; }\end{array}$ \\
\hline$>12.9$ & $\begin{array}{c}\text { Stop calculation }(\mathrm{FMA}=0) \text { and restart the } \\
\text { next day or when the rain ceases. }\end{array}$ \\
\hline
\end{tabular}

Table 2: $\quad$ FMA Fire danger classes.

\begin{tabular}{|c|c|}
\hline FMA values & Danger classes \\
\hline $0.0-1.0$ & Null \\
\hline $1.1-3.0$ & Small \\
\hline $3.1-8.0$ & Medium \\
\hline $8.1-20.0$ & High \\
\hline$>20.0$ & Very high \\
\hline
\end{tabular}

\subsection{Data grouping}

The information obtained from the data bank was grouped by decades and quinquennia, in the interval 1980 to 2009 . For each period (10 and 5 years) the 
fire occurrences were separated into two seasons: dry (May to September) and humid (October to April). In the simulations, the frequency tendency of fire occurrences in those periods, for each season, was compared to the traditional annual period. Therefore, three data groups by period (total annual, dry season, and humid season) were analyzed.

\subsection{Simulation algorithms}

The simulations for the ideal fire danger classes' calculation, for each data group per period, were made through a computer language. The programs were written according to the Visual FoxPro version 9, from the Microsoft Corporation [11] data bank manager. The calculation necessary for organizing the simulations were done according to the following algorithm steps:

a) Total fire occurrences frequency $\left(\right.$ Freq $\left._{\text {total }}\right)$ calculation in the data group by period;

b) Ideal frequency calculation, for each danger class, for the data group, according to the functions:

$$
\begin{gathered}
\text { Freq }_{\text {Null }}=0 ; \\
\text { Freq }_{\text {Small }}=0.029520295203 * \text { Freq }_{\text {total }} ; \\
\text { Freq }_{\text {Medium }}=0.232472324723 * \text { Freq }_{\text {total }} ; \\
\text { Freq }_{\text {High }}=0.291512915129 * \text { Freq }_{\text {total }} ; \\
\text { Freq }_{\text {Very high }}=\text { Freq }_{\text {total }}-\text { Freq }_{\text {Small }}-\text { Freq }_{\text {Medium }}-\text { Freq }_{\text {High }} ;
\end{gathered}
$$

where:

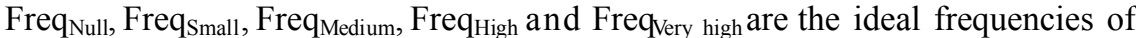

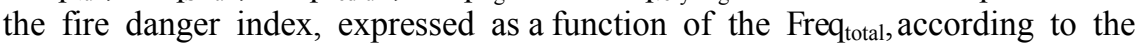
tendencies shown by Tetto et al. [9]. In the Figure 1 it is possible to observe that the ideal frequencies distribution follows a typical $4^{\circ}$ degree polynomial.

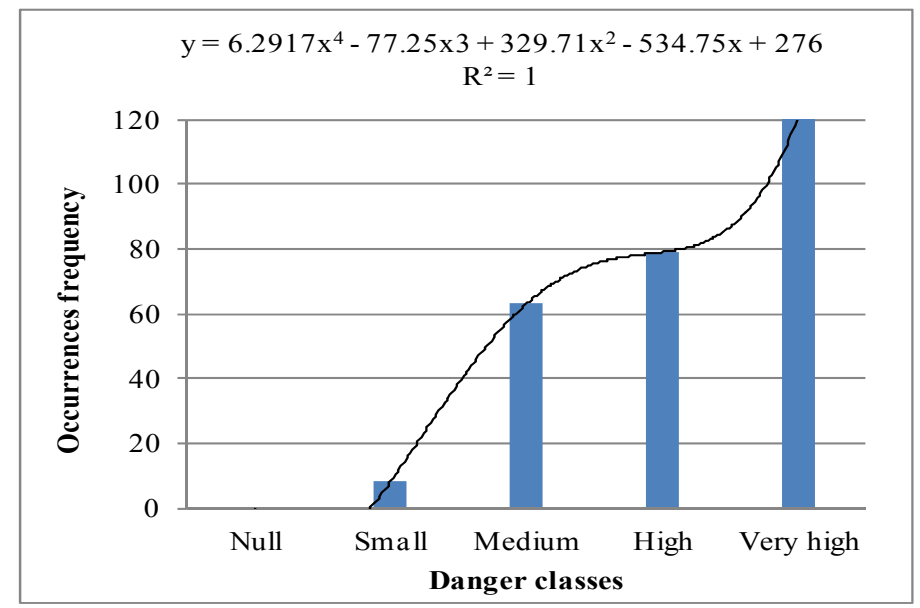

Figure 1: Fire occurrences distribution according to the FMA danger classes after the adjustment made by Tetto et al. [9]. 
c) To rank the data into the group, in decreasing order, according to the FMA value;

d) To search the archives, in the same decreasing order, until to find the last recorded data relative to the position of the Very High class frequency. To mark down this recorded FMA value that will be the lower limit of this danger class in the group;

e) Back to the archives; search the recorded data until the last value corresponding to the High class. To mark down this value that will be the lower limit of this danger class in the group;

f) The same for the Medium class values;

g) The same for the Small class values;

h) For the Null class, the frequency value is zero, therefore, its lower limit is zero;

i) Reclassify the group data with the new danger classes, considered the ideal values for the classes' limits.

j) To adjust the Small and Medium classes according to the lower limits of the original FMA, otherwise they would be underestimated;

k) To analyze the results for the adjusted group;

1) To repeat all the steps for the other groups.

The proposed adjustment and the original classification using the Mean Square Skill Score (MSSS) and the percentage of success were compared, according to Sampaio [12].

\section{Results and discussion}

The quinquennium period presented better results than the decade. For that reason this study will present only the results related to the 5 year periods. The proposed algorithm application started by the forest fire occurrences distribution according to the original FMA danger classes. The Table 3 shows the data tabulation according to the danger classes, separated by season and also by the traditional annual period.

The algorithm application generates a different data situation, due to the new limits (superior and inferior) for the danger classes (Table 4). However, the calculation leads to an underestimation of the Small class that in many situations disappears. For this reason it is necessary to readjust the class values because it is the starting point to the other classes. Therefore, the lower limit for the Small class was taken from the original FMA, that is, 1.01 (Table 5). It was also necessary to adjust the lower limit for the Medium class. The procedures are predicted in step " $\mathrm{j}$ " of the algorithm detailed in the methodology. The new limit was calculated through a proportional relation between the High class (with the original FMA value, 8.01) and the original value of the Medium class, 3.01. Using the "rule of three", the lower limits of the Medium class were calculated as follows: High class value times 3.01 divided by 8.01 . In that way, all the Medium class values were recalculated. With the estimated lower limits for the danger classes, a new occurrence distribution was obtained (Table 5). 
Table 3: Fire occurrence frequencies for the original danger index, with respective lower limits.

\begin{tabular}{|c|c|c|c|c|c|c|}
\hline \multicolumn{7}{|c|}{ Lower limits for the original danger index } \\
\hline Data & Period & $\mathbf{N}$ & $\mathbf{S}$ & $\mathbf{M}$ & $\mathbf{H}$ & VH \\
\hline Total annual & \multirow[t]{3}{*}{$\overline{1980-84}$} & 0 & 1.01 & 3.01 & 8.01 & 20.01 \\
\hline Humid season & & 0 & 1.01 & 3.01 & 8.01 & 20.01 \\
\hline Dry season & & 0 & 1.01 & 3.01 & 8.01 & 20.01 \\
\hline Total annual & \multirow[t]{3}{*}{ 1985-89 } & 0 & 1.01 & 3.01 & 8.01 & 20.01 \\
\hline Humid season & & 0 & 1.01 & 3.01 & 8.01 & 20.01 \\
\hline Dry season & & 0 & 1.01 & 3.01 & 8.01 & 20.01 \\
\hline Total annual & \multirow[t]{3}{*}{$1990-94$} & 0 & 1.01 & 3.01 & 8.01 & 20.01 \\
\hline Humid season & & 0 & 1.01 & 3.01 & 8.01 & 20.01 \\
\hline Dry season & & 0 & 1.01 & 3.01 & 8.01 & 20.01 \\
\hline Total annual & \multirow[t]{3}{*}{ 1995-99 } & 0 & 1.01 & 3.01 & 8.01 & 20.01 \\
\hline Humid season & & \begin{tabular}{|l|}
0 \\
\end{tabular} & 1.01 & 3.01 & 8.01 & 20.01 \\
\hline \begin{tabular}{|l|} 
Dry season \\
\end{tabular} & & \begin{tabular}{|l|}
0 \\
\end{tabular} & 1.01 & 3.01 & 8.01 & 20.01 \\
\hline Total annual & \multirow[t]{3}{*}{ 2000-04 } & 0 & 1.01 & 3.01 & 8.01 & 20.01 \\
\hline Humid season & & \begin{tabular}{|l|}
0 \\
\end{tabular} & 1.01 & 3.01 & 8.01 & 20.01 \\
\hline \begin{tabular}{|l|} 
Dry season \\
\end{tabular} & & \begin{tabular}{|l|}
0 \\
\end{tabular} & 1.01 & 3.01 & 8.01 & 20.01 \\
\hline Total annual & \multirow[t]{3}{*}{ 2005-09 } & 0 & 1.01 & 3.01 & 8.01 & 20.01 \\
\hline Humid season & & \begin{tabular}{|l|}
0 \\
\end{tabular} & 1.01 & 3.01 & 8.01 & 20.01 \\
\hline \begin{tabular}{|l|} 
Dry season \\
\end{tabular} & & \begin{tabular}{|c|}
0 \\
\end{tabular} & 1.01 & 3.01 & 8.01 & 20.01 \\
\hline
\end{tabular}

\begin{tabular}{|r|r|r|r|r|r|}
\hline \multicolumn{6}{|c|}{ Occurrence frequencies } \\
\hline $\mathbf{N}$ & $\mathbf{S}$ & $\mathbf{M}$ & $\mathbf{H}$ & $\mathbf{V H}$ & Total \\
\hline 1 & 5 & 31 & 35 & 54 & 126 \\
\hline 0 & 4 & 18 & 14 & 0 & 36 \\
\hline 1 & 1 & 13 & 21 & 54 & 90 \\
\hline 3 & 7 & 25 & 54 & 71 & 160 \\
\hline 3 & 5 & 13 & 27 & 6 & 54 \\
\hline 0 & 2 & 12 & 27 & 65 & 106 \\
\hline 1 & 6 & 31 & 65 & 68 & 171 \\
\hline 1 & 2 & 23 & 37 & 1 & 64 \\
\hline 0 & 4 & 8 & 28 & 67 & 107 \\
\hline 3 & 20 & 48 & 121 & 124 & 316 \\
\hline 3 & 12 & 29 & 64 & 18 & 126 \\
\hline 0 & 8 & 19 & 57 & 106 & 190 \\
\hline 9 & 36 & 124 & 210 & 133 & 512 \\
\hline 7 & 25 & 62 & 86 & 21 & 201 \\
\hline 2 & 11 & 62 & 124 & 112 & 311 \\
\hline 9 & 28 & 107 & 224 & 289 & 657 \\
\hline 5 & 15 & 49 & 91 & 58 & 218 \\
\hline 4 & 13 & 58 & 133 & 231 & 439 \\
\hline
\end{tabular}

$\mathrm{N}=$ Null $\mathrm{S}=$ Small $\mathrm{M}=$ Medium $\mathrm{H}=$ High $\mathrm{VH}=$ Very High

Table 4: $\quad$ Fire occurrence frequencies for the proposed danger indices; first simulation for the lower limits.

\begin{tabular}{|c|c|c|c|c|c|c|}
\hline \multicolumn{7}{|c|}{ Lower limits for the propose } \\
\hline Data & Period & $\mathbf{N}$ & $\mathbf{S}$ & $\mathbf{M}$ & $\mathbf{H}$ & $\overline{V H}$ \\
\hline otal annua & \multirow[t]{3}{*}{$1980-84$} & $\overline{0}$ & 0 & 2.95 & $\overline{7.19}$ & 18.5 \\
\hline Humid seaso & & 0 & 1.46 & 2.80 & 4.58 & 7 \\
\hline Dry seas & & 0 & 0 & 4.23 & 14.52 & 36.0 \\
\hline Total anr & \multirow[t]{3}{*}{ 1985-89 } & $\overline{0}$ & 0 & 1.47 & 8.92 & 20.4 \\
\hline Humid se & & 0 & 0 & $\overline{0}$ & 6.33 & 12.8 \\
\hline Dry seas & & 0 & 1.29 & 3.78 & 12.28 & 43.0 \\
\hline Total annual & \multirow[t]{3}{*}{$1990-94$} & $\overline{0}$ & 0 & 2.82 & 9.47 & 19.28 \\
\hline Humid se & & 0 & 0 & 2.82 & 5.13 & 10.3 \\
\hline Dry seaso & & 0 & 1.37 & 2.98 & 17.39 & 27.7 \\
\hline Total anr & \multirow[t]{3}{*}{$1995-99$} & $\overline{0}$ & $\overline{0}$ & 1.43 & 8.86 & 17.88 \\
\hline Humid se & & 0 & 0 & 1.35 & 7.20 & 11.9 \\
\hline Dry season & & 0 & 2.26 & 2.85 & 12.06 & 28.1 \\
\hline Total annual & \multirow[t]{3}{*}{ 2000-04 } & $\overline{0}$ & 0 & 1.41 & 6.21 & $13.2 \mathrm{c}$ \\
\hline Humid season & & 0 & 0 & $\overline{0}$ & 4.59 & 9.3 \\
\hline Dry seasc & & 0 & 0 & 2.45 & 8.65 & 17.6 \\
\hline Total ann & \multirow[t]{3}{*}{$2005-09$} & 0 & 0 & 1.47 & $\overline{9.18}$ & 19.0 \\
\hline Hum & & 0 & 0 & 1.25 & 7.29 & 12.4 \\
\hline Dry season & & 0 & 0 & 2.46 & 11.38 & 24.5 \\
\hline
\end{tabular}

$\mathrm{N}=$ Null $\mathrm{S}=$ Small $\mathrm{M}=$ =Medium $\mathrm{H}=$ High $\mathrm{VH}=$ =ery High 

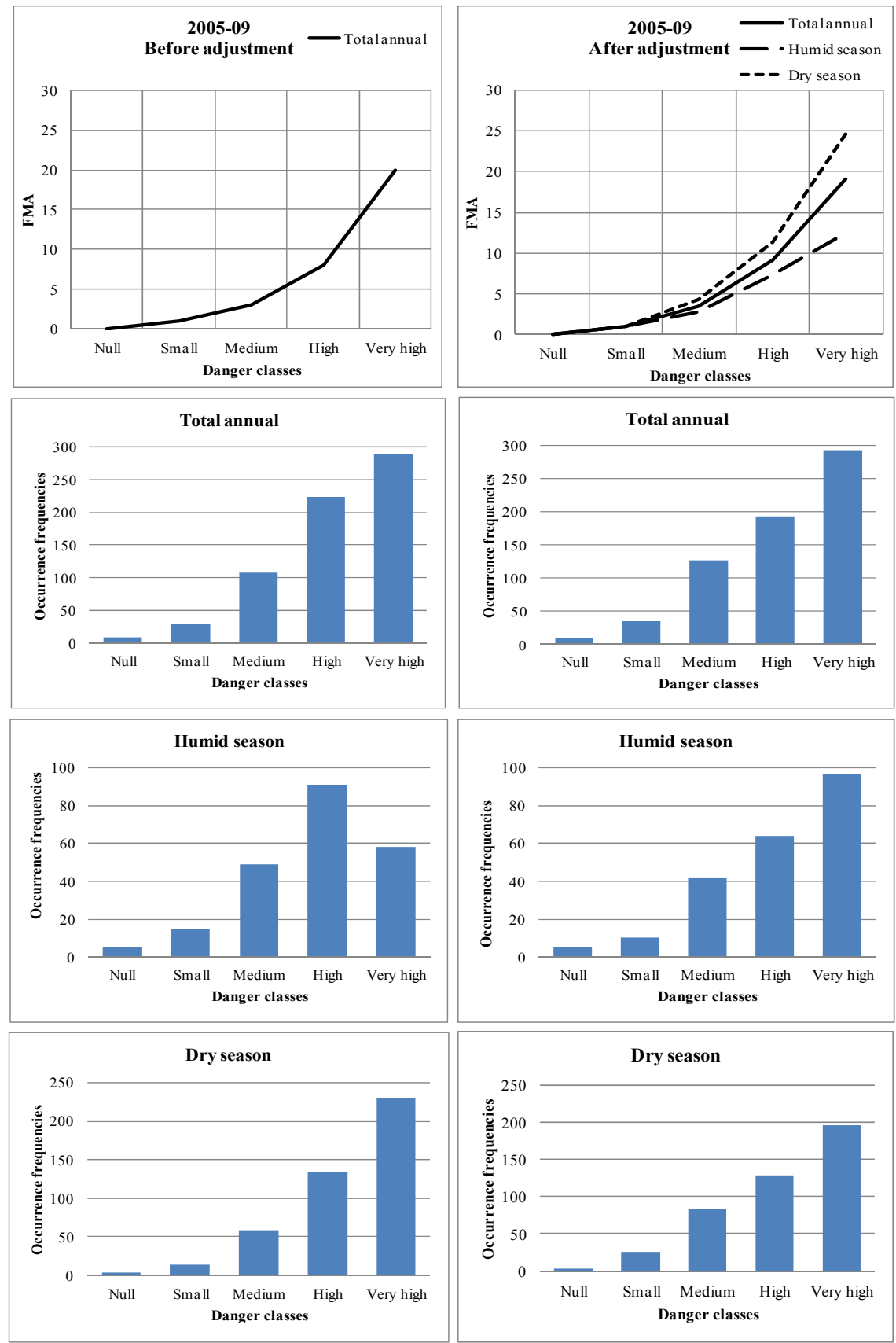

Figure 2: $\quad$ Forest fire occurrence frequencies by danger classes and season groups for the 2005-2009 quinquennium, before and after adjustment. 
Figure 2 shows the new fire occurrence frequencies distribution, separated by annual seasons for the 2005 -2009 quinquennium. The option for showing only this quinquennium is because the data from the other periods presented an analogous behavior (Table 5). Furthermore, for being the last analyzed period, the values represent a better reference to the current days.

Table 5: $\quad$ Fire occurrence frequencies for the proposed danger indices, with correct rounding for the lower limits.

\begin{tabular}{|c|c|c|c|c|c|c|}
\hline \multicolumn{7}{|c|}{ Lower limits for the proposed danger index } \\
\hline Data & Period & $\mathbf{N}$ & $\mathbf{S}$ & M & $\mathbf{H}$ & 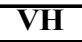 \\
\hline Total annual & \multirow[t]{3}{*}{$1980-84$} & 0 & 1.01 & 2.70 & 7.19 & 18.5 \\
\hline Humid seasor & & 0 & 1.01 & 1.72 & 4.58 & 7.19 \\
\hline Dry season & & 0 & 1.01 & 5.46 & 14.52 & 36.09 \\
\hline Total annual & \multirow[t]{3}{*}{$1985-89$} & 0 & 1.01 & 3.35 & 8.92 & $\overline{20.4}$ \\
\hline Humid season & & 0 & 1.01 & 2.38 & 6.33 & 12.8 \\
\hline Dry season & & 0 & 1.01 & 4.61 & 12.28 & 43.0 \\
\hline Total annual & \multirow[t]{3}{*}{ 1990-94 } & 0 & 1.01 & 3.56 & 9.47 & 19.28 \\
\hline Humid seasor & & 0 & 1.01 & 1.93 & 5.13 & 10.3 \\
\hline eason & & 0 & 1.01 & 6.53 & 17.39 & 27.7 \\
\hline Total annual & \multirow[t]{3}{*}{$1995-99$} & 0 & 1.01 & 3.33 & 8.86 & 17.8 \\
\hline Humid season & & 0 & 1.01 & 2.71 & 7.20 & 11.9 \\
\hline Dry season & & 0 & 1.01 & 4.53 & 12.06 & 28.1 \\
\hline Total annual & \multirow[t]{3}{*}{\begin{tabular}{|c|}
$2000-04$ \\
\end{tabular}} & $\overline{0}$ & 1.01 & 2.33 & 6.21 & 13.29 \\
\hline Humid season & & 0 & 1.01 & \begin{tabular}{|l|}
1.72 \\
\end{tabular} & 4.59 & 9.35 \\
\hline Dry season & & 0 & 1.01 & 3.25 & 8.65 & 17.66 \\
\hline Total annual & \multirow[t]{3}{*}{ 2005-09 } & 0 & 1.01 & 3.45 & 9.18 & 19.09 \\
\hline Humid seasor & & 0 & 1.01 & 2.74 & 7.29 & 12.45 \\
\hline Pry season & & 0 & 1.01 & 4.28 & 11.38 & $24.5^{\prime}$ \\
\hline
\end{tabular}

\begin{tabular}{|r|r|r|r|r|r|}
\hline \multicolumn{6}{|c|}{ Occurrence frequencies } \\
\hline $\mathbf{N}$ & $\mathbf{S}$ & $\mathbf{M}$ & $\mathbf{H}$ & $\mathbf{V H}$ & Total \\
\hline 1 & 2 & 30 & 37 & 56 & 126 \\
\hline 0 & 1 & 8 & 10 & 17 & 36 \\
\hline 1 & 8 & 15 & 26 & 40 & 90 \\
\hline 3 & 8 & 31 & 47 & 71 & 160 \\
\hline 3 & 3 & 9 & 16 & 23 & 54 \\
\hline 0 & 6 & 22 & 31 & 47 & 106 \\
\hline 1 & 7 & 37 & 50 & 76 & 171 \\
\hline 1 & 0 & 16 & 19 & 28 & 64 \\
\hline 0 & 11 & 17 & 31 & 48 & 107 \\
\hline 3 & 22 & 56 & 92 & 143 & 316 \\
\hline 3 & 8 & 22 & 37 & 56 & 126 \\
\hline 0 & 13 & 36 & 53 & 88 & 190 \\
\hline 9 & 15 & 109 & 149 & 230 & 512 \\
\hline 7 & 7 & 38 & 60 & 89 & 201 \\
\hline 2 & 11 & 68 & 91 & 139 & 311 \\
\hline 9 & 35 & 127 & 193 & 293 & 657 \\
\hline 5 & 10 & 42 & 64 & 97 & 218 \\
\hline 4 & 26 & 84 & 129 & 196 & 439 \\
\hline
\end{tabular}

$\mathrm{N}=$ Null $\mathrm{S}=$ Small $\mathrm{M}=$ Medium $\mathrm{H}=$ High $\mathrm{VH}=$ Very High

In Figure 2 the left graph shows the original FMA data and the right graph shows the calculated distribution after the proposed adjustment. In the total annual group the difference is minimum, but when separated by seasons, the difference is enhanced, what is positive to the methodology application and to the fire control activities.

\subsection{Methodology validation}

The objective of the adjustment of the danger degree classes was to obtain an optimization of the alert levels in order to become more efficient the fire control activities. For comparing the two situations, the frequency distribution of the number of days per danger class is presented for each analyzed quinquennium (Table 6). On the left are the data from the original FMA and on the right, the proposed adjustment. Again, the differences are noticeable when the data are separated by season. 
Table 6: Frequencies of days calculated with the proposed values for the danger classes compared to those obtained with the original FMA values, by quinquennium and season.

\begin{tabular}{|c|c|c|c|c|c|c|c|c|c|c|c|c|}
\hline \multicolumn{7}{|c|}{$\begin{array}{l}\text { Number of days in each class } \\
\text { for the original danger index }\end{array}$} & \multicolumn{6}{|c|}{$\begin{array}{l}\text { Number of days in each class } \\
\text { for the propos ed danger index }\end{array}$} \\
\hline \multicolumn{7}{|c|}{ Total annual } & \multicolumn{6}{|c|}{ Total annual } \\
\hline \begin{tabular}{|l|} 
Period \\
\end{tabular} & $\overline{\mathbf{N}}$ & $\overline{\mathbf{S}}$ & $\overline{\mathbf{M}}$ & $\overline{\mathbf{H}}$ & $\mathbf{V H}$ & Total & $\mathbf{N}$ & $\overline{\mathbf{S}}$ & $\overline{\mathbf{M}}$ & $\overline{\mathbf{H}}$ & VH & Total \\
\hline 1980-84 & 237 & 382 & 568 & 475 & 165 & 1827 & 237 & 338 & 537 & 523 & 192 & 1827 \\
\hline \begin{tabular}{|l|}
$1985-89$ \\
\end{tabular} & 213 & 351 & 500 & 502 & 260 & 1826 & 213 & 371 & 544 & 449 & 249 & 1826 \\
\hline \begin{tabular}{|l|}
$1990-94$ \\
\end{tabular} & 208 & 369 & 574 & 517 & 158 & 1826 & 208 & 419 & 635 & 390 & 174 & 1826 \\
\hline \begin{tabular}{|l|}
$1995-99$ \\
\end{tabular} & 227 & 390 & 529 & 481 & 199 & 1826 & 227 & 420 & 561 & 370 & 248 & 1826 \\
\hline $2000-04$ & 211 & 360 & 563 & 540 & 153 & 1827 & 211 & 221 & 518 & 523 & 354 & 1827 \\
\hline $2005-09$ & 200 & 345 & 531 & 497 & 253 & 1826 & 200 & 379 & 581 & 396 & 270 & 1826 \\
\hline total & $\begin{array}{l}1296 \\
\text { Humi }\end{array}$ & 2197 & 3265 & 3012 & 1188 & 10958 & 1296 & 2148 & 3376 & 2651 & 1487 & 10958 \\
\hline Period & $\mathbf{N}$ & $\mathbf{S}$ & $\mathbf{M}$ & $\overline{\mathbf{H}}$ & $\mathbf{V H}$ & Total & $\overline{\mathbf{N}}$ & $\mathbf{S}$ & $\bar{M}$ & $\overline{\mathbf{H}}$ & VH & Total \\
\hline 1980-84 & 158 & 258 & 376 & 244 & 26 & 1062 & \begin{tabular}{l|}
158 \\
\end{tabular} & 128 & 260 & 196 & 320 & 1062 \\
\hline \begin{tabular}{|l|}
$1985-89$ \\
\end{tabular} & 143 & 237 & 342 & 305 & 34 & 1061 & 143 & 151 & 333 & 274 & 160 & 1061 \\
\hline \begin{tabular}{|l|}
$1990-94$ \\
\end{tabular} & 136 & 243 & 367 & 284 & 31 & 1061 & 136 & 120 & 307 & 286 & 212 & 1061 \\
\hline \begin{tabular}{|l|}
$1995-99$ \\
\end{tabular} & 158 & 283 & 330 & 251 & 39 & 1061 & 158 & 245 & 334 & 169 & 155 & 1061 \\
\hline $2000-04$ & 136 & 231 & 360 & 294 & 41 & 1062 & 136 & 112 & 248 & 298 & 268 & 1062 \\
\hline 2005-09 & 131 & 232 & 360 & 272 & 66 & 1061 & 131 & 205 & 354 & 188 & 183 & 1061 \\
\hline total & $\begin{array}{r}862 \\
\text { Dry s }\end{array}$ & 1484 & 2135 & 1650 & 237 & 6368 & $\begin{array}{r}862 \\
\text { Dry se }\end{array}$ & $\begin{array}{r}961 \\
\text { as on }\end{array}$ & 1836 & 1411 & 1298 & 6368 \\
\hline \begin{tabular}{|l|} 
Period \\
\end{tabular} & $\mathbf{N}$ & $\mathbf{S}$ & $\mathbf{M}$ & $\overline{\mathbf{H}}$ & $\mathbf{V H}$ & Total & $\mathbf{N}$ & $\mathbf{S}$ & $\mathbf{M}$ & $\overline{\mathbf{H}}$ & \begin{tabular}{|l|}
$\mathbf{V H}$ \\
\end{tabular} & Total \\
\hline $1980-84$ & 79 & 124 & 192 & 231 & 139 & 765 & 79 & 228 & 246 & 144 & 68 & 765 \\
\hline \begin{tabular}{|l|}
$1985-89$ \\
\end{tabular} & 70 & 114 & 158 & 197 & 226 & 765 & 70 & 170 & 187 & 233 & 105 & 765 \\
\hline \begin{tabular}{|l|}
$1990-94$ \\
\end{tabular} & 72 & 126 & 207 & 233 & 127 & 765 & 72 & 281 & 258 & 82 & 72 & 765 \\
\hline \begin{tabular}{|l|}
$1995-99$ \\
\end{tabular} & 69 & 107 & 199 & 230 & 160 & 765 & 69 & 169 & 231 & 219 & 77 & 765 \\
\hline $2000-04$ & 75 & 129 & 203 & 246 & 112 & 765 & 75 & 137 & 210 & 201 & 142 & 765 \\
\hline 2005-09 & 69 & 113 & 171 & 225 & 187 & 765 & 69 & 162 & 213 & 174 & 147 & 765 \\
\hline total & 434 & 713 & 1130 & 1362 & 951 & 4590 & 434 & 1147 & 1345 & 1053 & 611 & 4590 \\
\hline
\end{tabular}

The figure 3 presents the 2005-2009 quinquennium data, extracted from Table 6. On the left are the graphs corresponding to the original FMA and on the right the distribution calculated with the proposed danger classes' values.

It can be observed an improvement in the distribution throughout the classes, which became more homogeneous, with an increase in the number of days in the Medium and a decrease in the higher classes, what would lead to an economy in the fire prevention costs.

Apparently, there was degradation in the humid season, due to the increase in the number of days in the Very High class and a decrease in the High and Small. This situation demanded a checking in the calculation and a new simulation. However, the values were confirmed because no bias was detected. The option to decrease the Very High class values and increase the High class would cause a deformation in the observed occurrences frequencies in this season group.

The adjustment presented a higher MSSS and success rate compared to the original classification. This confirmed the hypothesis that the imbalance observed was caused by the change, over time, in the precipitation regimen and, consequently, in the relative humidity. 

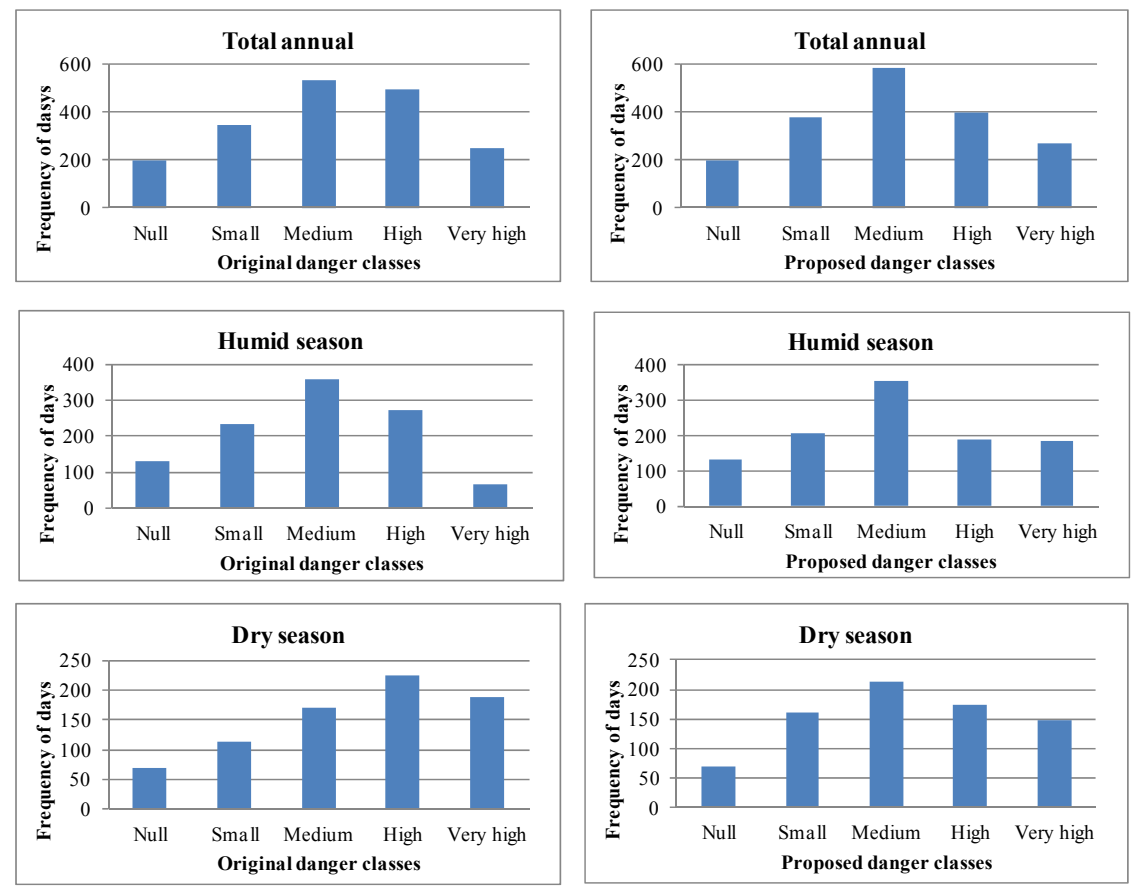

Figure 3: Daily danger classes distribution by season group for the 20052009 quinquennium, before and after adjustment.

\section{Conclusions}

The proposed new danger class limits are viable and present a better equilibrium in the daily index values distribution.

The data separation by seasons, dry and humid, made possible to treat the index with particular emphasis in the higher fire danger period.

In the humid season the higher fire occurrence frequency was observed in the Very High danger class.

The quinquennium division was very useful and for the analyzed period it is recommended to use the last quinquennium, from 2005 to 2009.

It is recommended to make a new simulation in 2014, replicating the same algorithm, to actualize the index for the next quinquennium.

The proposed methodology could be used for adjusting the FMA to other Brazilian geographic regions.

\section{References}

[1] Soares, R. V.; Batista, A. C. Incêndios florestais: controle, efeitos e uso do fogo. Curitiba: FUPEF, 2007. 264p. 
[2] Nunes, J. R. S.; Soares, R. V.; Batista, A. C. FMA+ - Um Novo Índice de Perigo de Incêndios florestais para o Estado do Paraná - Brasil. Revista Floresta, Curitiba, v.36, n. 1, p. 75-91, 2006.

[3] Batista, A. C. Incêndios florestais. Recife: UFRPE, 1990. 115 p.

[4] Nunes, J. R. S.; Fier, I. S. N.; Soares, R. V.; Batista, A. C. Desempenho da Fórmula de Monte Alegre (FMA) e da Fórmula de Monte Alegre Alterada $\left(\mathrm{FMA}^{+}\right)$no Distrito Florestal de Monte Alegre. Revista Floresta, Curitiba, v.40, n.2, p.319-326, 2010.

[5] Viegas, D. X. Et al. Calibração do sistema canadiano de perigo de incêndio para aplicação em Portugal. Silva Lusitana, Lisboa, v.12, n.1, p.77-93, 2004.

[6] Soares, R. V. Índices de perigo de incêndio. Revista Floresta, Curitiba, v.3, n.3, p.19-40, 1972a.

[7] Marletto, L.; Ventura, F. Indici meteorologici per il calcolo del rischio d'incendio forestale. Available in: HTTP://www.agrometeorologia.it/ documenti/aiam2002/175-184Marletto.pdf Access on May 14, 2009.

[8] Soares, R. V. Determinação de um índice de perigo de incêndio para a região centro-paranaense, Brasil. M.Sc. Thesis - Centro Tropical de Ensino e Investigação, Instituto Interamericano de Ciências Agrícolas da OEA Turrialba, Costa Rica,1972b. 72p.

[9] Tetto, A. F.; Batista, A. C.; Soares, R. V.; Nunes, J. R. S. Comportamento e ajuste da Fórmula de Monte Alegre na Floresta Nacional de Irati, Estado do Paraná. Scientiae Forestalis, Piracicaba, v.38, n.87, p.409-417, set. 2010.

[10] Maack, R. Geografia física do Estado do Paraná. Banco de Desenvolvimento do Paraná. Curitiba. 1968. 350 p.

[11] MICROSOFT CORPORATION. Microsoft FoxPro language reference. Relational database management system for MS-DOS and Windows. Redmond, Wa, 1989-1993. Software Manual.

[12] SAMPAIO, O. B. Análise da eficiência de quatro índices na previsão de incêndios florestais para a região de Agudos - SP. 157f. Tese (Doutorado em Engenharia Florestal) - Setor de Ciências Agrárias, Universidade Federal do Paraná, Curitiba, 1999. 